\title{
INFLUENCE OF ROOTSTOCKS ON WINTER-HARDINESS OF PLUM GENERATIVE BUDS DURING THE WINTERING PERIOD IN TWO GROWING REGIONS
}

\author{
Dzintra Dēḳena ${ }^{1}$, Ina Alsiṇa ${ }^{2}$, Valda Laugale ${ }^{1}$, and Kersti Kahu ${ }^{3}$ \\ ${ }^{1}$ Institute of Horticulture, Latvia University of Life Sciences and Technologies, 1 Graudu Str., Ceriṇi, Krimūnu pag., Dobele, LV-3124, \\ LATVIA \\ ${ }^{2}$ Institute of Soil and Plant Sciences, Latvia University of Life Sciences and Technologies, Lielā iela 2, Jelgava, LV-3001, LATVIA \\ ${ }^{3}$ Polli Horticultural Research Centre, Estonian University of Life Sciences,Polli, Karksi-Nuia 69101, Viljandimaa, ESTONIA \\ \# Corresponding author, dzintra.dekena@ llu.Iv
}

Contributed by Ina Alsin̨a

The selection of appropriate rootstock is the main precondition for obtaining a high yielding and sustainable plum orchard. In the Northern climate, plum overwintering is especially important, where winter hardiness of flower buds is one of indicators. This investigation was carried out during three wintering periods (2010-2013) at the Institute of Horticulture in Püre (Latvia) and the Polli Horticultural Research Centre (Estonia), in orchards planted in 2001. The aim of the investigation was to evaluate the influence of different rootstocks on the viability of flower buds during winter for two plum cultivars in two growing regions. European plum 'Victoria' and hybrid plum 'Kubanskaya Kometa' grafted on eight clonal and eight seedling rootstocks were used in the investigation. Bud samples were taken two times during winter: end of January and end of March. The viability of flower buds and flowering intensity were determined in the laboratory. The viability was determined as dehydrogenase activity using triphenyl tetrazole chloride $(0.5 \%)$, where in living cells the colourless substance due to enzymatic activity turns into a brightly coloured product - formasan. The optical density of colour was determined with a spectrophotometer at $485 \mathrm{~nm}$. Both cultivars 'Kubanskaya Kometa' and 'Victoria' had higher flower bud viability in Polli compare to Püre. In both growing regions, the highest activity of dehydrogenases for cultivar 'Kubanskaya Kometa' was on rootstocks 'Myrobalan', 'St. Julien INRA 2', 'Wangenheims Zwetsche' and for cultivar 'Victoria' - on rootstocks 'Ackermann', 'Brompton' seedlings, and 'St. Julien d' Orleans'. The dehydrogenase activity of in flower buds had a tendency to decrease during winter.

Key words: Prunus, flower buds, flowering intensity, enzymatic activity, meteorological conditions, Latvia, Estonia.

\section{INTRODUCTION}

Climatic conditions of both Latvia and Estonia are characterised by sharp air temperature fluctuations, when frosts interchange with thaws at the end of winter. The appropriate choice of cultivar/rootstock combinations that increase tree resistance to different unfavourable conditions is one of preconditions to obtaining high yield (Wertheim, 1998).

Caucasian plum (Prunus cerasifera Ehrh.) seedlings were the most widely used rootstocks for a long period in Latvia and Estonia, but they are not suitable for modern plum orchards because they grow too vigorously and are incompati- ble with several cultivars (Lepsis et al., 2004; Rozpara et al., 2010).

To increase the productivity of plum orchards, flower bud winter hardiness is very important (Tyurina et al., 2000). According to previous reports in the literature, flower buds are the most sensitive part of stone fruit trees (Palonen and Buszard, 1997). The winter hardiness of flower buds can vary greatly among different species, depending on the time and course of the flower bud dormancy period. Frost resistance of flower buds decreases after the beginning of vegetative growth. The end of winter is especially hazardous for flower buds, when air temperature increases and flower 
buds have finished the periods of endodormancy and ecodormancy (Proebsting, 1982; Tyurina et al., 2000; Allona et $a l ., 2008)$. Therefore, the level of damage to flower buds after frost can differ between wintering periods (Szalay et al., 2017). The cultivar has a high importance in flower bud winter hardiness. In a study on evaluation of rootstocks in Estonia, during spring 2004, the home plum cultivar 'Victoria' had all flower buds damaged by frosts, whereas the diploid plum cultivar 'Kubanskaya Kometa' was less damaged and produced fruits (Jänes et al., 2007).

The temperature regime before and after the critical minimum is very important in the resistance of the flower buds. During winters when temperature decreases gradually and a negative low temperature is observed before critically strong frosts, plants undergo sufficient hardening. In such winters, the damage to flower buds is insignificant. Strong flower bud damage is observed in winters when there is a temperature increase followed by a very sharp decrease of temperature. Flower bud frost resistance differs among cultivars also when buds are in the same developmental stage (Enache and Baciu, 2016). The damage severity can be higher on an open field compared to in the laboratory, because the amount of hours with minimal temperature that have impact on plants differs. In laboratory conditions, the amount of hours is usually limited (Holubowicz and Bojar, 1982).

The freezing processes in fruit tree flower buds are more complicated than in wood tissue (Rodrigo, 2000). In flower buds, the formation of ice begins at the scion of the bud and in the base of the flower that is located in front of the main organs of the flower. Ice crystals may occur in selected places in the bud, and not be distributed evenly throughout the bud (Tromp et al., 2005). The base of the bud and generative tissues are the most sensitive.

The aim of the investigation was to evaluate the influence of different rootstocks on the viability of flower buds during winter for two widespread plum cultivars in two growing regions of Latvia and Estonia.

\section{MATERIALS AND METHODS}

Plant material. The plum cultivars 'Kubanskaya Kometa' (Prunus rossica. Erem.) and 'Victoria' (Prunus domestica L.) were grafted on eight seedling rootstocks (St. Julien INRA 2, St. Julien d'Orleans, St. Julien Noir, Brompton, Wangenheims Zwetsche, St. Julien Wädenswil, and Myrobalanand Prunus cerasifera var. divaricate), and eight clonal rootstocks ('St. Julien A', 'Brompton', 'Ackermann', 'Pixy', 'GF8/1', 'G5/22', 'GF655/2', and 'Hamyra'). The study was performed at the Institute of Horticulture in Pūre, Latvia, and at the Polli Horticultural Research Centre, Estonia. The experimental orchards were established in spring 2001. Plants were planted at a space of $3 \times 5 \mathrm{~m}$, in four replications, with three trees per plot. The soil type was clay loam in Pūre, and sandy clay loam in Polli. Bud samples were taken two times during the wintering period: in the end of January and end of March. The viability of flower buds and flowering intensity were determined at the laboratory of Plant Physiology of University of Life Sciences and Technologies. The viability was determined as activity of dehydrogenases using triphenyltetrazole chloride $(0.5 \%)$, where in living cells the colourless substance due to enzymatic activity turns into a brightly coloured product — formasan (TTCF) (Anonymous, 2012). The optical density of colour was determined with a spectrophotometer at wavelength $485 \mathrm{~nm}$. Data were analysed using descriptive statistics and ANOVA. Differences between means were tested by the least significant difference (LSD) and Duncan's criteria at a $5 \%$ significance level.

Meteorological conditions. Meteorological data were collected at the local meteorological stations in both trial places. Minimal, maximal, and average air temperatures during winters in 2010/2011, 2011/2012, and 2012/2013 are presented in Table 1. Significant differences in meteorological parameters were observed among years whereas they did not differ significantly between growing regions. The air temperature fluctuation trend during winter was similar between the growing regions. The lowest air temperature

MINIMAL, MAXIMAL AND AVERAGE AIR TEMPERATURES DURING THE WINTERS OF 2010/2011, 2011/2012 AND 2012/2013

\begin{tabular}{|c|c|c|c|c|c|c|c|c|c|c|}
\hline \multirow[t]{2}{*}{ Month } & \multirow{2}{*}{ Region } & \multicolumn{3}{|c|}{$2010 / 2011$} & \multicolumn{3}{|c|}{$2011 / 2012$} & \multicolumn{3}{|c|}{$2012 / 2013$} \\
\hline & & $\min$ & $\max$ & average & $\min$ & $\max$ & average & $\min$ & $\max$ & average \\
\hline \multirow[t]{2}{*}{ October } & Polli & -4.3 & 12.9 & 4.1 & -0.8 & 15.5 & 7.3 & -5.1 & 17.1 & 5.7 \\
\hline & Pūre & -3.2 & 15.3 & 4.8 & -2.0 & 18.1 & 7.9 & -5.7 & 18.8 & 6.5 \\
\hline \multirow[t]{2}{*}{ November } & Polli & -21.9 & 11.3 & 0.2 & -6.6 & 9.9 & 3.9 & -7.7 & 8.2 & 2.7 \\
\hline & Pūre & -15.2 & 13.3 & 2.4 & -6.2 & 11.0 & 5.0 & -1.1 & 10.0 & 4.4 \\
\hline & Pūre & -18.0 & 0.7 & -6.2 & -4.9 & 9.5 & 2.0 & -17.1 & 5.5 & -5.8 \\
\hline \multirow[t]{2}{*}{ January } & Polli & -22.1 & 3.0 & 4.2 & -21.7 & 4.2 & -5.1 & -27.2 & 4.0 & -6.6 \\
\hline & Pūre & -16.9 & 3.7 & -2.4 & -22.5 & 6.4 & -2.8 & -21.1 & 5.7 & -7.7 \\
\hline \multirow[t]{2}{*}{ February } & Polli & -33.5 & 2.3 & -11 & -32.1 & 3.1 & -10.2 & -19.8 & 5.3 & -2.9 \\
\hline & Pūre & -28.5 & 4.5 & -8.9 & -29.7 & 8.2 & -7.7 & -20.9 & 8.2 & -6.4 \\
\hline & Pūre & -16.9 & 8.7 & 0.1 & -13.0 & 15.0 & 1.8 & -19.3 & 8.4 & -5.4 \\
\hline
\end{tabular}


was observed in February 2010/2011, when temperature dropped to $-33.5{ }^{\circ} \mathrm{C}$ in Polli and to $-28.5{ }^{\circ} \mathrm{C}$ in Pūre. In Polli in February 2011/2012, the air temperature also dropped below $-30.0{ }^{\circ} \mathrm{C}$. The winter of 2010/2011 was especially cold, because frosts below $-10.0{ }^{\circ} \mathrm{C}$ were observed from November to March in both trial locations, and the temperature in Pūre was $-16.9{ }^{\circ} \mathrm{C}$ even in March.

\section{RESULTS}

In Pūre, the lowest activity of dehydrogenases for cultivar 'Kubanskaya Kometa' was observed in flower bud samples collected in January and March of 2011. In the three-year period of study, the biggest differences among rootstocks in winter were observed in March (Table 2). During all three winters, this cultivar had the most stable results on rootstocks 'St. Julien d' Orleans', 'Wangenheims Zwetsche', 'Myrobalan' 'Ackermann' and 'Brompton' seedlings.

Comparing both growing regions, the difference in dehydrogenase activity between January and March was larger in Pūre, which can be explained by greater fluctuation between minimal and maximal air temperatures. In both study locations, for cultivar 'Kubanskaya Kometa' the most stable combinations with higher dehydrogenase activity were with rootstocks 'Myrobalan', 'St. Julien INRA 2', 'Wangenheims Zwetsche', P. cerasifera var. divaricata and 'St. Julien d’ Orleans' (Fig. 1).

During three winters, cultivar 'Victoria' had lower dehydrogenase activity than for 'Kubanskaya Kometa'. In general,

Table 2

DEHYDROGENASES ACTIVITY IN FLOWER BUDS OF CULTIVAR 'KUBANSKAYA KOMETA' DURING WINTERS OF THE YEARS 2010/2011,

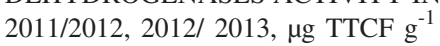

\begin{tabular}{|c|c|c|c|c|c|c|}
\hline \multirow[t]{2}{*}{ Rootstocks } & \multicolumn{3}{|c|}{ Pūre } & \multicolumn{3}{|c|}{ Polli } \\
\hline & January & March & Average & January & March & Average \\
\hline Ackermann & $2.35 \mathrm{ab}^{*}$ & $3.83 \mathrm{abcd}$ & 3.09 & $5.10^{* *}$ & $1.96 \mathrm{a}$ & 3.53 \\
\hline St. Julien INRA2 & $1.74 \mathrm{a}$ & $2.28 \mathrm{abc}$ & 2.01 & 5.49 & $3.57 \mathrm{ab}$ & 4.53 \\
\hline Brompton seedlings & $2.00 \mathrm{ab}$ & $3.60 \mathrm{abcd}$ & 2.80 & 3.96 & $5.25 \mathrm{~b}$ & 4.60 \\
\hline Myrobalan & $2.57 \mathrm{ab}$ & $6.02 \mathrm{~d}$ & 4.29 & 5.17 & $3.76 \mathrm{ab}$ & 4.47 \\
\hline GF 8/1 & $2.53 \mathrm{ab}$ & $3.18 \mathrm{abcd}$ & 2.85 & 5.00 & $3.14 \mathrm{ab}$ & 4.07 \\
\hline G 5/22 & $2.71 \mathrm{ab}$ & $2.92 \mathrm{abcd}$ & 2.81 & 3.27 & $3.00 \mathrm{ab}$ & 3.13 \\
\hline St.Julien d’ Orleans & $3.38 \mathrm{ab}$ & $5.34 \mathrm{~cd}$ & 4.36 & 4.81 & $4.17 \mathrm{ab}$ & 4.49 \\
\hline Brompton clonal & $2.79 \mathrm{ab}$ & $1.96 \mathrm{abcd}$ & 2.38 & 3.04 & $3.68 \mathrm{ab}$ & 3.36 \\
\hline St. Julien Noir & $2.66 \mathrm{ab}$ & $1.92 \mathrm{ab}$ & 2.29 & 3.08 & $3.24 \mathrm{ab}$ & 3.16 \\
\hline St. JulienWädenswill & $2.78 \mathrm{ab}$ & $3.38 \mathrm{abcd}$ & 3.08 & 3.02 & $3.19 \mathrm{ab}$ & 3.11 \\
\hline WangenheimsZwetsche & $3.42 \mathrm{ab}$ & $4.58 \mathrm{abcd}$ & 4.00 & 3.86 & $2.19 \mathrm{a}$ & 3.02 \\
\hline St Julien A & $2.44 \mathrm{ab}$ & $1.73 \mathrm{a}$ & 2.08 & 2.52 & $2.06 \mathrm{a}$ & 2.29 \\
\hline Pixy & $3.36 \mathrm{ab}$ & $2.34 \mathrm{abcd}$ & 2.85 & 2.95 & $2.15 \mathrm{a}$ & 2.55 \\
\hline Hamyra & $2.73 \mathrm{ab}$ & $3.48 \mathrm{abcd}$ & 3.11 & 3.55 & $2.59 \mathrm{ab}$ & 3.07 \\
\hline P. cerasifera var. divaricata & $4.32 \mathrm{a}$ & $5.25 \mathrm{bcd}$ & 4.78 & 3.43 & $2.60 \mathrm{ab}$ & 3.02 \\
\hline GF $655 / 2$ & $2.29 \mathrm{ab}$ & $2.73 \mathrm{abc}$ & 2.51 & 5.00 & $2.61 \mathrm{ab}$ & 3.81 \\
\hline Average & 2.75 & 3.41 & 3.08 & 3.95 & 3.07 & \\
\hline
\end{tabular}

* values within columns marked by different letters have significant difference (Duncan's criteria, $p=0.05$ )

*** no statistically significant difference between values within column

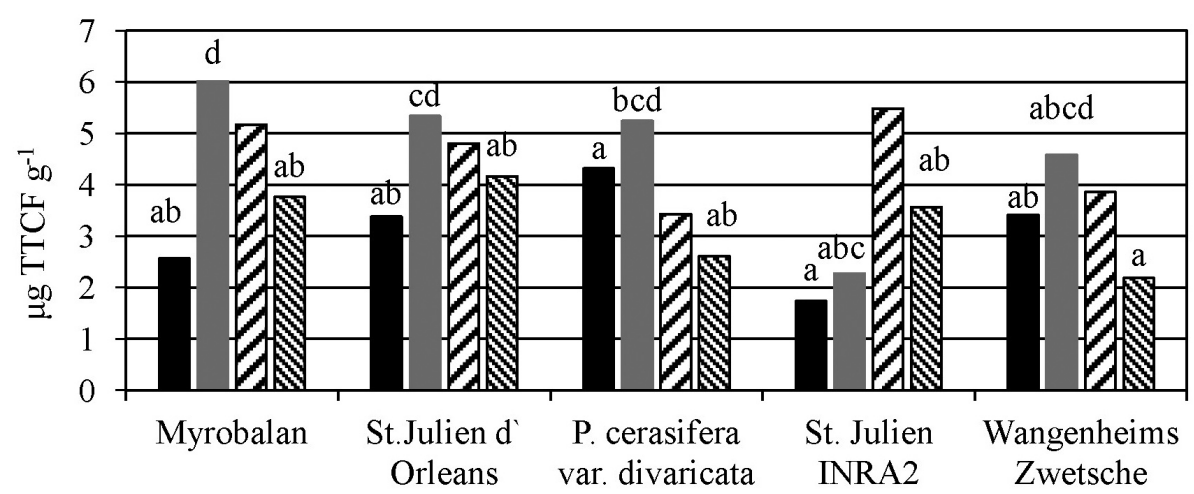

Rootstocks

Pūre, January

- Pūre, March

口 Polli, January

\$ Polli, March

Fig. 1. Rootstocks with the highest dehydrogenase activity in flower buds for the cultivar 'Kubanskaya Kometa' (values within columns marked by different letters over the months have significant difference, Duncan's criteria, $p=0.05$ ). 
for both trial locations and winters evaluated, the dehydrogenase activity was higher for trees grafted on rootstocks 'Ackermann', 'Brompton' seedlings, 'St. Julien d' Orleans', 'GF8/1', 'Pixy' and P. cerasifera var. divaricata (Table 3).

In Polli, the highest dehydrogenase activity for all rootstocks in general was observed during winter of 2010/2011, while the lowest was in March of 2013, when for some cultivar/rootstock combinations there was an insufficient amount of living buds for analysis of dehydrogenase activity.

Significant differences among sampling times for cultivar 'Victoria' were observed for all three winters $(p=0)$, where lower dehydrogenase activity was observed in March compared to January. The highest dehydrogenase activity was observed in Polli for trees on rootstock 'Ackermann' in January (5.73 $\mu \mathrm{g} \mathrm{TTCF} \cdot \mathrm{g}^{-1}$ ) (Fig. 2).
In both trial locations, rootstocks 'Ackermann', 'Brompton' seedlings, 'St. Julien d Orleans', 'St. Julien Noir', 'GF 8/1' were selected as the most favourable for cultivar 'Victoria', as they had the highest dehydrogenase activity.

\section{DISCUSSION}

To increase plum orchard productivity in northern European countries, flower bud winter hardiness is very important. Significant differences among sampling times were found for dehydrogenases activity, and among cultivar/rootstock combinations and growing regions.

In Polli, during three winters, cultivar 'Kubanskaya Kometa' had more stable results regarding dehydrogenase activity in flower buds compared to that in Pūre. In January, significant differences among rootstocks were not found

Table 3 DEHYDROGENASES ACTIVITY IN FLOWER BUDS OF CULTIVAR 'VICTORIA' DURING WINTERS OF YEARS 2010/2011, 2011/2012, 2012/ 2013, $\mu \mathrm{g}$ TTCF $\mathrm{g}^{-1}$

\begin{tabular}{|c|c|c|c|c|c|c|}
\hline \multirow[t]{2}{*}{ Rootstocks } & \multicolumn{3}{|c|}{ Pūre } & \multicolumn{3}{|c|}{ Polli } \\
\hline & January & March & Average & January & March & Average \\
\hline Ackermann & $4.15 c^{*}$ & $3.51 \mathrm{ab}$ & 3.83 & $5.73 \mathrm{~b}$ & $3.34 \mathrm{~b}$ & 4.54 \\
\hline St. Julien INRA2 & $2.19 \mathrm{ab}$ & $1.57 \mathrm{a}$ & 1.88 & $2.54 \mathrm{a}$ & $0.92 \mathrm{a}$ & 1.73 \\
\hline Brompton seedlings & $2.12 \mathrm{ab}$ & $4.45 \mathrm{~b}$ & 3.29 & $3.74 \mathrm{ab}$ & $2.14 \mathrm{ab}$ & 2.94 \\
\hline Myrobalan & $2.30 \mathrm{ab}$ & $2.66 \mathrm{ab}$ & 2.48 & $2.73 \mathrm{a}$ & $2.48 \mathrm{ab}$ & 2.60 \\
\hline GF $8 / 1$ & $3.36 \mathrm{bc}$ & $2.44 \mathrm{ab}$ & 2.90 & $3.66 \mathrm{ab}$ & $1.85 \mathrm{ab}$ & 2.75 \\
\hline G 5/22 & $2.79 \mathrm{abc}$ & $1.35 \mathrm{a}$ & 2.07 & $2.59 \mathrm{a}$ & $0.88 \mathrm{a}$ & 1.73 \\
\hline St.Julien d` Orleans & $2.53 \mathrm{abc}$ & $2.88 \mathrm{ab}$ & 2.71 & $3.58 \mathrm{ab}$ & $2.99 \mathrm{ab}$ & 3.28 \\
\hline Brompton clonal & $1.25 \mathrm{a}$ & $2.72 \mathrm{ab}$ & 1.98 & $4.14 \mathrm{ab}$ & $1.99 \mathrm{ab}$ & 3.07 \\
\hline St. Julien Noir & $2.05 \mathrm{ab}$ & $2.80 \mathrm{ab}$ & 2.42 & $3.26 a b$ & $2.27 \mathrm{ab}$ & 2.77 \\
\hline St. JulienWädenswill & $2.47 \mathrm{abc}$ & $2.57 \mathrm{ab}$ & 2.52 & $3.42 \mathrm{ab}$ & $1.85 \mathrm{ab}$ & 2.63 \\
\hline WangenheimsZwetsche & $2.41 \mathrm{abc}$ & $1.43 \mathrm{a}$ & 1.92 & $2.06 \mathrm{a}$ & $1.32 \mathrm{ab}$ & 1.69 \\
\hline St Julien A & $2.69 \mathrm{abc}$ & $2.09 \mathrm{ab}$ & 2.39 & $2.68 \mathrm{a}$ & $1.89 \mathrm{ab}$ & 2.29 \\
\hline Pixy & $3.09 \mathrm{abc}$ & $2.26 \mathrm{ab}$ & 2.68 & $3.19 \mathrm{ab}$ & $1.82 \mathrm{ab}$ & 2.50 \\
\hline Hamyra & $2.53 \mathrm{abc}$ & $2.12 \mathrm{ab}$ & 2.32 & $2.90 \mathrm{a}$ & $1.23 \mathrm{ab}$ & 2.06 \\
\hline P. cerasifera var. divaricata & $2.38 \mathrm{abc}$ & $2.80 \mathrm{ab}$ & 2.59 & $2.45 \mathrm{a}$ & $1.15 \mathrm{a}$ & 1.80 \\
\hline GF $655 / 2$ & $1.52 \mathrm{ab}$ & $1.79 \mathrm{a}$ & 1.66 & $3.22 \mathrm{ab}$ & $2.03 \mathrm{ab}$ & 2.62 \\
\hline Average & 2.49 & 2.46 & 2.48 & 3.24 & 1.88 & \\
\hline
\end{tabular}

*values within columns marked by different letters have significant difference (Duncan's criteria, $p=0.05$ ).

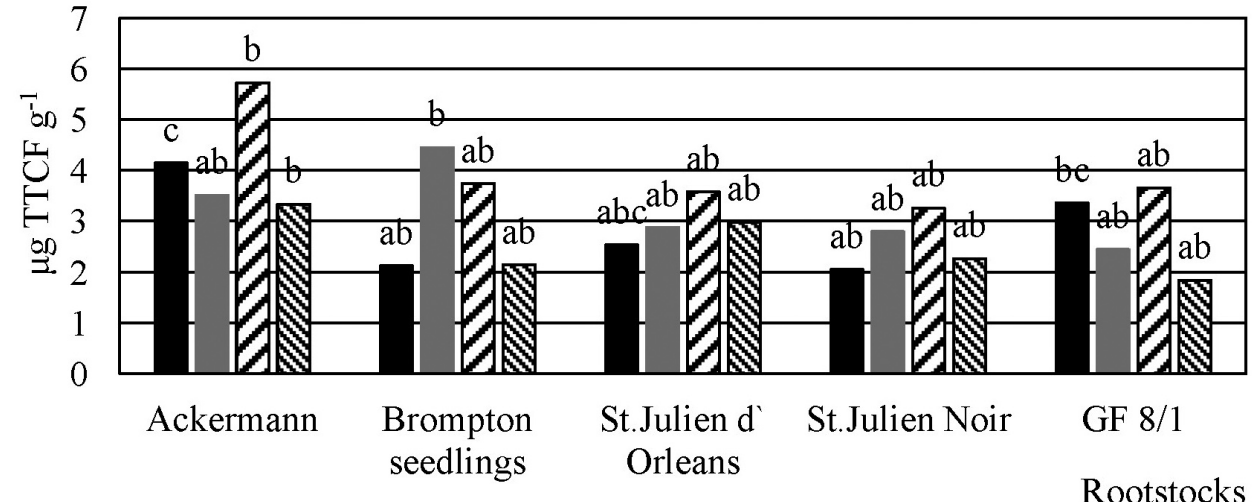

Pūre, January $\quad$ Pūre, March $\quad$ QPolli, January $\$$ Polli, March
Fig. 2. Rootstocks with the highest dehydrogenase activity in flower buds for the cultivar 'Victoria' (values within columns marked by different letters over the months have significant difference, Duncan's criteria, $p=0.05$ ). 
(Duncan's criteria). This can be explained by greater fluctuations between the minimum and maximum air temperatures during winter. According to Yeryomin and Safarov (2013), cultivar 'Kubanskaya Kometa' is characterised by high winter hardiness in Southern regions of Russia, whereas in Latvia and Estonia tree and flower bud damage is observed during winter (Jänes and Kahu, 2008; Lepsis et al., 2008). The winter hardiness of this cultivar can be also influenced by thaws during winter, as it belongs to the $P$. cerasifera plum group that has a short dormancy period. During the dormancy period it can withstand even drops in temperature to $-30{ }^{\circ} \mathrm{C}$, whereas after the dormancy period, the resistance to low temperatures sharply decreases and then it can withstand temperature -10 to $-15{ }^{\circ} \mathrm{C}$ only for a short period (Yeryomin, 1993).

\section{CONCLUSIONS}

Both cultivars 'Kubanskaya Kometa' and 'Victoria' had higher flower bud viability at Polli compared to Pūre. In both growing regions, the highest dehydrogenase activity for cultivar 'Kubanskaya Kometa' was on rootstocks 'Myrobalan', 'St. Julien INRA 2', and 'Wangenheims Zwetsche', and for cultivar 'Victoria' on rootstocks 'Ackermann', 'Brompton' seedlings, and 'St. Julien d' Orleans'. The dehydrogenase activity in flower buds has a tendency to decrease during winter.

\section{REFERENCES}

Allona, I., Ramos, A., Ibanez, C., Contreras, A., Casado, R., Aragoncillo, C. (2008). Molecular control of winter dormancy establishment in trees. Spanish J. Agricult. Res., 6, 201-210.

Anonymous (2012). Modified method of: Volkov, F. A., Yaroslavtsev, E. N., Vlasova, T. N. Determination of winter hardiness of fruit and berry crops to cold season stressors in field and controlled conditions [Ф. А. Волков, Е. Н. Ярославцев, Т. Н. Власова. Определение устойчивости плодовых и ягодных культур к стресорам холодного времени года в полевых и контролируемых условиях (метод. указ.)]. Moscow, 2002, p. 119 (in Russian).

Enache, V., Baciu, A. A. (2016). Influence of temperature in dormancy period on fruit buds of some stone fruit tree species. J. Horticult. For. Biotechnol., 20, 17-23.
Holubowicz, T., Bojar, K. (1982). Cold tolerance studies of one year shoots of eight black currant cultivar. Fruit Sci. Rep., 9 (3), 91-99.

Jänes, H., Kahu, K. (2008). Winter injuries of plum cultivars in winters 2005-2007 in Estonia. In: Proceedings of International Scientific Conference "Sustainable Fruit Growing: From Plant to Product", 28-31 May 2008, Jūrmala, Dobele, Latvia. Latvia State Institute of Fruit Growing, Dobele, pp. 149-153.

Jänes, H., Klaas, L., Pae, A. (2007). Winter hardiness of plum on different rootstocks in winter 2002/2003 in Estonia. Acta Hort., 734, 295-298.

Lepsis, J., Dēķena, Dz., Dēķens, V. (2008). Evalution of European plum rootstocks in Latvia. In: Proceedingsof International Scientific Conference "Sustainable Fruit Growing: From Plant to Product", 28-31 May 2008, Jūrmala, Dobele, Latvia. Latvia State Institute of Fruit Growing, Dobele, pp. 77-82.

Lepsis, J., Drudze, I., Dekens, U. (2004). The evaluation of different plum and pear rootstocks in the nursery. Acta Hort., 658, 167-171.

Palonen, P., Buszard, D. (1997). Current state of cold hardiness research on fruit crops. Can. J. Plant. Sci., 77, 399-420.

Proebsting, E. L. (1982). Cold Resistance of Stone Fruit Flower Buds. Issued by cooperative extension of Washington State University. $7 \mathrm{pp}$.

Rodrigo, J. (2000). Spring frosts in deciduous fruit trees - morphological damage and flower hardiness. Scientia Hort., 85, 155-173.

Rozpara, E., Glowacka A., Grzyb Z. S., (2010). The growth and yields of plum cultivars grafted on two rootstocks in central Poland. Acta Hort., 874, 255-259.

Sitarek, M., Grzyb, Z., Kozinski, B. (2007). Effect of four different rootstocks on the growth, yield and fruit quality of 'Valor' plum trees. Acta Hort., 734, 413-416

Szalay, L., Molnar, A., Kovacs, S. (2017). Frost hardiness of flower buds of three plum (Prunus domestica L.) cultivars. Scientia Hort., 214, 228-232.

Tromp, J., Webster, A., Wertheim, S. (2005) Fundamentals of Temperate Zone Tree Fruit Production. Backuys Publishers, Leiden. 400 pp.

Tyurina, M. M., Demenko, V. I., Goloulina, L. K., Eczedi, J. J. Arsentyev, A. P. (2000). Physiology of winter toleration, growth and fructification by fruit and small fruit plants. In: Scientific Works of the International Conference "The History, Present Time and the Perspective Progress of the Russian Horticulture”. Moscow, pp. 192-220 (in Russian).

Wertheim, S. J. (1998). European plum. In: Rootstock Guide. Fruit research station, Wilhelminadorp, The Netherlands, pp. 115-137.

Yeryomin, G. (1993). Breeding of winter hardy stone fruit cultivars in the North Caucasus [Селекция зимостойких сортов косточковых культур на Северном Кавказе]. In: Breeding for Winterhardiness of Fruit and Berries Plants [Селекция на зимостойкость плодовых и ягодных культур], Moscow, pp. 48-54 (in Russian).

Yeryomin, G., Safarov, P. (2013). Intensive Technologies for Growing of Russian plum [Интенсивные технологии воздельвания сливы Русской]. Krimsk. 35 pp. (in Russian).

\section{POTCELMU IETEKME UZ PLŪMJU GENERATĪVO PUMPURU ZIEMCIETĪBU ZIEMOŠANAS PERIODA LAIKĀ DIVOS AUDZĒŠANAS REĢIONOS}

Piemērotu potcelmu izvēle ir galvenais priekšnoteikums ilgtspējīgu plūmju dārzu ierīkošanā. Ziemeḷu klimatā ziedpumpuru ziemcietîba ir viens no galvenajiem rādītājiem. Pētījums veikts 2001. gadā ierīkotā izmēǵinājumā, Dārzkopības institūtā Pūrē (Latvija) un Polli Dārzkopības pētījumu centrā, no 2010. līdz 2013. gadam. Pētījuma mērkis bija izvērtēt dažādu plūmju potcelmu ietekmi uz ziedpumpuru ziemcietību divām šḳirnēm divos audzēšanas reǵionos. Pētījumā izmantota Eiropas plūmju šḳirne 'Viktorija' un hibrīdplūme 'Kubanskaja Kometa', kas potētas uz astoṇiem ǵeneratīvi vairotiem un astoṇiem veǵetatīvi vairotiem potcelmiem. Ziedpumpuru paraugi ievākti divas reizes ziemošanas periodā — janvārī un martā. Ziedpumpuru dzīvotspēja noteikta kā dehidrogenāzes aktivitāte, izmantojot 0,5\% trifeniltetrazola hlorīdu. Salīdzinot abas izmēgéninājuma vietas, augstāka ziedpumpuru dzīvotspēja abām šḳirnēm bija Polli. Abās izmēg̣inājumu vietās augstākā ziedpumpuru dehidrogenāzes aktivitāte šḳirnei 'Kubanskaja Kometa' bija uz potcelmiem 'Myrobalan', St. Julien d' Orleans', 'Wangenheims Zwetcshe' un škirnei 'Viktorija' - uz potcelmiem 'Ackermann' 'Brompton' ġeneratīvi vairotiem, 'St. Julien d' Orleans'. Ziedpumpuru dehidrogenāzes aktivitātei ir tendence ziemošanas perioda laikā samazināties. 